\title{
Impact of Monetary Policy on Indonesia's Economic Growth, Case Studies before and during the Covid-19 Pandemic
}

\author{
Dini Hariyanti ${ }^{1}$, Victor Siagian, Soeharjoto ${ }^{2}$ \\ \{dinihariyanti@trisakti.ac.id ${ }^{1}$, soeharjoto@trisakti.ac.id ${ }^{2}$ \} \\ Faculty of Economics and Business, Universitas Trisakti, Indonesia ${ }^{1,2}$
}

\begin{abstract}
One of the main drivers of a country's economic growth is monetary policy. The purpose of this research is to see if the monetary policies implemented by the central bank during the covid 19 pandemic had an impact on Indonesia's growth, as measured by macroeconomic factors. Based on the processing results, the independent variable used influences economic growth by using time series and dummy data for the period before and after the Covid19 pandemic during the 2015-2020 period. Monetary policy, interest rate, inflation, exchange rates, and the Covid-19 pandemic dummy are all factors that influence economic growth. Interest rates, on the other hand, have no effect. Due to the significant risk of economic uncertainty, it is clear that the strategy of decreasing interest rates, which is meant to encourage investment, has no effect on the economy during the pandemic. The implication of this study shows that the fiscal policy carried out by the government is appropriate to increase people's purchasing power.
\end{abstract}

Keywords: Economic Growth; Money Supply; Interest Rates; Inflation; Exchange Rates; Covid-19 Pandemic

\section{Introduction}

Indonesia's economic growth rate in 2019 was 5.02 percent lower than in 2018, when it was 5.17 percent [1]. This is reflected in Indonesia's Gross Domestic Product, which was ranked 16th in 2019. In terms of purchasing power parity (PPP), the country's economic growth is ranked 7th in the world [2]. Strong economic growth is intrinsically related to the influence of the monetary and financial sectors, both of which are thought to be more or less successful policy strengths. This is because, through the transmission mechanism, the monetary sector has a bigger influence on the real sector's operation, including investment, output, and consumption activities, which affects inflation. The influence of the monetary and financial sectors, which are deemed more or less effective strengths achieved by policy, is inextricably linked to high economic growth. This is because, through the transmission mechanism, the monetary sector has a greater influence on the real sector's operation, including investment, production, and consumption activities, all of which affect aggregate output lev. 
According to Pricewaterhouse Coopers (PWC) estimates, Indonesia's PPP Economic Growth rating will improve to fifth in 2030 and fourth in 2050, as indicated in [3]. This is due to a number of variables, including the fact that Indonesia's population will continue to expand through 2050, rising from fourth place in the world in 2030 to fifth place in 2050. The second reason is that. Second, because Indonesia's economic distribution is still larger than developed countries. Third, the position of Indonesia, which is still in the developing stage, has a relatively larger portion of the productive age population in accordance with the demographic bonus. Meanwhile, the population in developed countries is getting older, so that relatively few can work with high productivity. Several countries' economies contracted at the start of 2020, when the Covid-19 Pandemic broke out in Wuhan. Several of Indonesia's trading partners' economies shrank sharply and became negative. Singapore was down 2.2 percent, Hong Kong was down 8.9 percent, the European Union was down 2.7 percent, and China was down $6.8 \%$. [4].

Indonesia's macroeconomic conditions are approaching a period of recession, according to a report released by the Ministry of Finance, Sri Mulyani Indrawati in September 2020, with economic growth declining for two consecutive quarters. Economic growth slowed from a negative 5.32 percent in September's first quarter to a negative 2.9 percent in September's second quarter. In general, the economy will grow in 2020. The economy will grow at a negative 1.7 percent to 0.6 percent rate in 2020. Fiscal stimulus has been used by the government to implement macro policy [4] by reallocating funds from the financial sector to health, social protection, and national economic recovery. According to the evidence, monetary policy is one of the most important factors in a country's economic growth [5]. [6]. Furthermore, some earlier academics have been concerned in recent years about the transmission mechanism of monetary policy (see [7]; [8]; and [9].

The monetary policy transmission mechanism explains how the central bank's monetary policy influences various economic and financial activity in order to reach the stated goal in the end. The monetary policy transmission mechanism, according to [10], is "the process through which monetary policy decisions are transferred into changes in real economic growth and inflation." The monetary policy transmission mechanism in Indonesia can be seen through several channels, namely the interest rate channel, the exchange rate channel, the bank lending channel, the bank balance sheet and asset prices, as shown in the following figure.

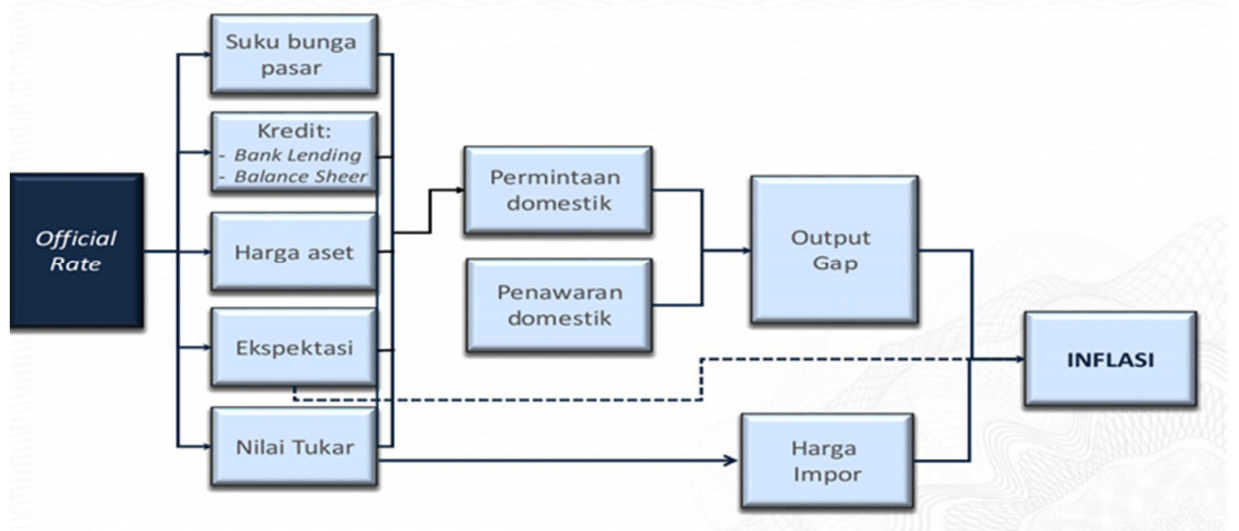

Fig. 1. Transmission Mechanism Line Sources: bi.go.id (2020) 
Bank Indonesia, as the monetary authority, utilizes the interest rate as an instrument to affect credit demand through market operations, based on the transmission mechanism outlined above. As a result, interest rates will cause aggregate demand to follow market demand. Short-term interest rates are used to start the transmission mechanism, which eventually spreads to medium-term and long-term interest rates [11]. When the government implements a tight monetary policy, interest rates rise, causing a drop in numerous bankingrelated sectors as prices rise. Several prior studies concluded that the exchange rate channel had a negligible impact on economic growth, McCarthy is currently in [6]. The majority of research on credit lines indicates that increasing credit leads to increased economic growth. The majority of research, on the other hand, refutes the linear relationship between credit and economic growth. According to [12] and [6], credit has little effect on economic growth. This is due to defaults and a lack of government oversight.

In terms of channel interest rates, most studies show that there is no relationship between investment spending and market interest rates, implying that monetary policy's influence on economic growth via the interest rate channel is limited, leading to some countries pursuing mixed monetary policies, such as through the asset price channel. Given the context, it is clear that understanding whether monetary policy has an impact on economic growth is critical, given that monetary policy's objective is to drive the economy. Furthermore, it is becoming more crucial to examine the impact of monetary policy on the Indonesian economy during the COVID-19 pandemic. This study examines the impact of monetary policy on economic growth during the Covid-19 epidemic by looking at the money supply, repo interest rate, price level, and exchange rate.

\section{Theoretical Review}

Classical economic growth theory is a foundation of growth theory that has been used in the past and continues to be used today. Economic thinkers like Adam Smith and David Ricardo proposed the classical economic growth hypothesis. In his book "An Inquiry into the Nature and Causes of the Wealth of Nations," Adam Smith makes a systematic argument on the long-term mechanism of economic progress. Total output growth and population expansion, according to Smith, are the two main aspects of economic growth. The population is regarded as a non-active factor. As a result, a country's growth is more dependent on output growth. While production growth is mostly influenced by capital invested, capital is determined by profit earned. Profit is determined by the market (demand), which in turn is determined by the population. Wages are essential to the population. Wages are determined by productivity. Natural factors are constant, according to the classical assumption. So, at some point, the level of production will achieve "Full Employment," which means that the amount of output can no longer be increased because it has reached its maximum level. As a result, the pay level will remain unchanged, because if wages remain unchanged, the population will remain unchanged, as wages determine the cost of living for the population. As a result, achieving "Full Employment" means that the economy will stagnate, and the economy will eventually become a static and mediocre economic sub-system. In concept, David Ricardo's hypothesis is identical to Adam Smith's proposal. Assuming that natural conditions remain constant and that the population continues to expand at a rapid rate, the level of economic development will eventually be very low and will cease to develop.

The Bank of Indonesia (BI) Rate is the policy interest rate that represents the Bank of Indonesia's monetary policy stance and is made public. The BI Rate is a monthly financial 
policy made by BI, followed by a meeting of members of the board of governors to assess the general economic situation at home and abroad. The BI Rate was then determined using monetary operations to reflect BI's attitude toward these situations. The validity of the interest rate channel of the Bank of Russia's monetary policy transmission mechanism gives indicate that interest rate policy is partly efficient following the global financial crisis, according to study conducted by [13].

Inflation is one of the most important variables in determining the BI Rate's value. The rise and fall of inflation will cause prices of products and services to rise or fall in general and over time. The BI Rate will be determined by the rate of inflation as it rises and falls. Bank Indonesia will boost the BI Rate if inflation rises. Bank Indonesia, on the other hand, will cut the BI Rate if inflation lowers. An increase in currency demand is attributable to a rise in the demand for money transactions, or possibly a rise in the speculative desire for money. Money demand transactions will be strongly linked to the country's level of economic activity, gross domestic income (GDI) or gross domestic product (GDP), and the level of worker demand. The higher a country's unemployment rate, the less individuals will be able to spend money on products and services in general. In Indonesia, the Central Bank, in this case, Bank Indonesia, finds it difficult to alter the money supply in a timely manner to accommodate changes in inventory in the demand for money related to business transactions.

Foreign currency rates are employed in trade transactions. The exchange rate indicates how much rupiah is required to obtain foreign currency. The exchange rate, according to [11], is the price of one unit of foreign currency in domestic currency. In other terms, the exchange rate is the cost of exchanging one currency for another. The rupiah to dollar exchange rate is commonly used. Because the dollar is a relatively stable economic currency. A stable exchange rate tends to indicate a stable economic condition because a stable exchange rate indicates good monetary stability and various monetary and banking transactions are running smoothly.

However, the appreciation of the exchange rate and the depreciation of the exchange rate affect economic growth. When the exchange rate depreciates, the impact is that the production of export-oriented goods and services will increase because prices abroad will be higher than prices at home, so it will be more expensive. It is also profitable if the goods and services are exported. The greater the export, the foreign exchange reserves will increase and the productivity of export-oriented goods and services will increase, which will increase economic growth in general [12]. Based on a study conducted by [13] on the effect of the exchange rate regime on economic growth They underlined the significance of an accompanying monetary policy framework to the exchange rate system. [14] asserted the same thing, demonstrating that depending on preferences and the monetary policy that accompanies the exchange rate regime, either a fixed or floating exchange rate system could give a higher degree of economic growth. According to [10], the Bank of Russia's current tight monetary policy appears to be fairly acceptable in the face of highly fluctuating exchange rates. Economic growth is not hampered by economic actors' excessive inflation. After making significant progress in improving the effectiveness of the monetary policy transmission mechanism by switching to an inflation targeting and settlement regime for interest rate setting, the Bank of Russia will be able to boost economic agents' confidence and increase the effectiveness of interest rate policies by maintaining the regime and increasing the monetary base.

\section{Hypothesis Development}

The money supply, interest rate, inflation and the exchange rates has a significant effect on economic growth both before and during the Covid-19 pandemic. 


\section{Research Method}

The independent variable's impact on the dependent variable is examined using an econometric model based on multiple linear regression models. The ordinary least squares method, often known as the OLS (Ordinary Least Square) method, was used to estimate. When estimating linear regression equations, this OLS approach is most commonly utilized [15]. The following equation model is applied using time series data and dummy periods before and after the Covid-19 Pandemic from 2015 to 2020.

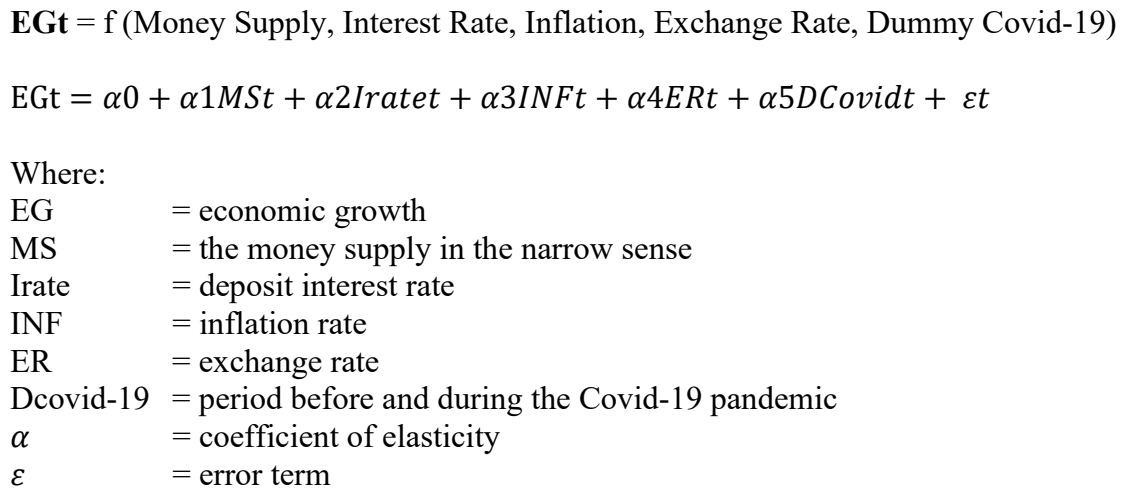

The type of data used in this study is panel data (cross section and time series) from 2009 to september 2020. This data is obtained from secondary data, namely data that has been published by a trusted official institution or institution. The sources of data used are secondary data that has been published and issued by the bank of Indonesia and the central bureau of statistics.

\section{Results and Discussion}

Based on the results of descriptive statistics, the variable economic growth in Indonesia has a minimum value of 2158,040 with a maximum value of 2818,890 and the average value (mean) obtained from 69 observations is 2509,476 and a standard deviation of 186,6876 . The standard deviation value indicates that the research data for the economic growth variable has a value of more than one, which means that the research data for the economic growth variable is varied. The variable amount of money in circulation has a minimum value of 4174,830 with a maximum value of 6748,570 , and the average value (mean) obtained from 69 observations is 5294,233 and the standard deviation is 695,0827 . The value of the standard deviation indicates that the research data for the money supply variable as a proxy for monetary policy has a value of more than one, which means that the research data for the money supply variable is varied.

The variable deposit interest rate has a minimum value of 5.790000 with a maximum value of 8.790000, and the average value (mean) obtained from 69 observations is 7.075217 and the standard deviation is 0.794830 . The value of the standard deviation shows a value smaller than the number one, which means that the research data for the deposit interest rate variable is not diverse or homogeneous. The inflation variable has a minimum value of negative 1.730000 with a maximum value of 4.950000, and the average value (Mean) obtained from 69 
observations is 2.732174 and the standard deviation is 1.739838 . The standard deviation value indicates that the research data for the inflation variable has a value of more than one, which means that the research data for the inflation variable is varied. The Exchange Rate variable has a minimum value of 12672.00 with a maximum value of 16310.00 , and the average value (mean) obtained from 69 observations is 13839.16 and a standard deviation of 638.8389 . The standard deviation value indicates that the research data for the exchange rate variable has a value of less than one, which means that the research data for the exchange rate variable is less varied.

\begin{tabular}{|c|c|c|c|c|c|}
\hline & EG & MS & Irate & INF & ER \\
\hline Mean & 2509.476 & 5294.233 & 7.075217 & 2.732174 & 13839.16 \\
\hline Median & 2508.970 & 5321.430 & 6.910000 & 3.530000 & 13751.00 \\
\hline Maximum & 2818.890 & 6748.570 & 8.790000 & 4.950000 & 16310.00 \\
\hline Minimum & 2158.040 & 4174.830 & 5.790000 & -1.730000 & 12672.00 \\
\hline Std. Dev. & 186.6876 & 695.0827 & 0.794830 & 1.739838 & 638.8389 \\
\hline Skewness & -0.144985 & 0.191213 & 0.754545 & -1.021838 & 0.973364 \\
\hline Kurtosis & 1.888984 & 2.068849 & 2.431207 & 3.200712 & 4.737814 \\
\hline Jarque-Bera & 3.790515 & 2.913216 & 7.477531 & 12.12358 & 19.57803 \\
\hline Probability & 0.150280 & 0.233025 & 0.023783 & 0.002330 & 0.000056 \\
\hline Sum & 173153.8 & 365302.1 & 488.1900 & 188.5200 & 954902.0 \\
\hline Sum Sq. Dev. & 2369954. & 32853517 & 42.95932 & 205.8384 & 27751833 \\
\hline Observations & 69 & 69 & 69 & 69 & 69 \\
\hline
\end{tabular}

\subsection{Classic Assumption Test}

Before testing the theoretical hypothesis, the classical assumption is tested first. From the classical assumption test, it can be concluded that the theoretical hypothesis testing can be continued because there are two classical assumptions that are violated, namely multicollinearity and autocorrelation. For this reason, the regression model was improved by performing autocorrelation healing using the rho coefficient. The results of processing the model of the level of economic activity after there is an improvement are shown in table 4.2. The classic assumption test after the autocorrelation improvement can be explained as follows: a. The results of the normality test concluded that the distribution of the residuals was normal as indicated by the prob value of the jarque berra of $0.03744>0.01$, which means Ho is accepted so that the data distribution of the normal residuals is at alpha $1 \% \mathrm{~b}$. Multicollinearity testing using VIF produces a VIF value $<10$ for all independent variables used, namely Money Supply, Deposit Interest Rates, Inflation, and the exchange rate, so that it can be concluded that in the resulting model there is no multicollinearity. c. Autocorrelation testing using the LM test produces a prob value of the LM test of $0.1814>0.05$, which means Ho is accepted, so that it can be achieved that in the resulting model there is no autocorrelation problem. d. Heteroscedasticity testing using the white test results in a prob value of the white test of $0.4438>0.05$, which means Ho is accepted, so that it can be achieved that the resulting model does not have heteroscedasticity. 


\subsection{Statistical Regression Results}

The fit model is indicated by the adjusted R2 value of 0.865981 , which means that the variation or behaviour of the independent variables, namely Money Supply, deposit interest rate, Inflation, Exchange Rate, DCovid-19, is able to explain the variation of the behaviour of the dependent variable, namely the level of economic activity (EG), while the rest, $14.41 \%$, is a variation of other independent variables that affect EG but are not included in the model. These results indicate that the EG model for conventional banks has a good goodness of fit. The results of the global test ( $F$ test) are indicated by the prob value of $F$ of $0.000<0.05$, which means Ho is rejected (Ha is accepted) so that it can be concluded that there is at least 1 independent variable that has a significant effect on the level of economic activity (EG).

Table 2. Estimation Results of Economic Activity Level Model

\begin{tabular}{|c|c|c|c|c|}
\hline \multicolumn{5}{|c|}{ Dependent Variable: EG } \\
\hline Variable & Coefficient & t statistic & Prob. & VIF \\
\hline MS & 0.259493 & 8.014422 & 0.0000 & 7.333874 \\
\hline Irate & -21.79824 & -1.040760 & 0.1502 & 3.723450 \\
\hline INF & -10.16612 & -1.313524 & 0.0969 & 3.047392 \\
\hline ER & 0.019972 & 1.350446 & 0.0909 & 1.943693 \\
\hline DCOVID-19 & -163.3029 & -6.985633 & 0.0000 & 2.288325 \\
\hline $\mathrm{R}^{2}$ Adjusted & 0,865981 & Jarque Berra & 6,56961 & \\
\hline F statistic & 87,5856 & Prob & 0,03744 & \\
\hline Prob & 0.000 & White & 19,20481 & \\
\hline LM test & 1,78610 & Prob & 0.4438 & \\
\hline Prob & 0,1814 & & & \\
\hline
\end{tabular}

\subsection{Analysis}

The research hypothesis testing was carried out on the 5 hypotheses proposed, namely: Hypothesis 1 aims to examine the effect of Money Supply on Economic Growth. From the calculation results, the estimated coefficient value is 0.259493 , which means that Money Supply has a positive effect on Economic Growth where increasing Money supply will increase Economic Growth and vice versa. With a t-statistic of 8.0144, the prob value of 0.000 0.05 means that Ho is rejected and $\mathrm{Ha}$ is accepted, so it can be concluded that the positive effect of Money Supply on Economic Growth is significant.

Hypothesis 2 was conducted to examine the negative effect of the Deposit Interest Rate on Economic Growth. The processing result is indicated by a coefficient value of-21.79824, which means that an increase in the deposit interest rate will reduce Economic Growth and it is better if a decrease in the deposit interest rate will increase Economic Growth. With a statistical $t$ value of-1.040760, the prob value of $0.3020 / 2=0.1501>0.05$, which means Ho is accepted, so that it can be concluded that it is not proven that deposit interest rates have a negative effect on Economic Growth.

Hypothesis 3 aims to examine the negative effect of inflation on Economic Growth. From the calculation results, the estimated coefficient value is -10.16612 , which means that increasing inflation will decrease Economic Growth and vice versa, decreasing inflation will increase Economic Growth. With a t statistic of -1.313524 , the prob value of $0.0919<0.1$ is obtained so that Ho is rejected (Ha is accepted). These findings indicate that the theoretical 
hypothesis which states that there is a negative effect of inflation on Economic Growth is proven.

Hypothesis 4 is carried out with the aim of testing the positive effect of the exchange rate on Economic Growth. The calculation results are shown by the estimated coefficient value of 0.019972 , which means that increasing the value of the rupiah against the dollar (depreciation) will increase Economic Growth and conversely, decreasing the value of the rupiah against the dollar (appreciation) will decrease Economic Growth. With a t-statistic value of 1.350446, the prob value of $0.0909<0.10$ means that $\mathrm{Ho}$ is rejected (Ha is accepted) so that it can be concluded that the positive effect of the exchange rate on Economic Growth is significant.

Hypothesis 5 aims to test the positive effect of Covid-19 on Economic Growth. From the calculation results, an estimated coefficient of -163.3029 is obtained, which means that there are differences in the level of economic activity before and after Covid-19, where the level of economic activity after Covid-19 is lower than the level of economic activity before Covid-19. With a t-statistic value of -6.985633 , a prob value of $0.000<0.05$ means Ho is rejected and Ha is accepted, so it can be concluded that Covid-19 caused the activity level to decrease compared to conditions before Covid-19.

\subsection{Discussion}

The money supply has a strong effect on economic growth in terms of the sign and magnitude of the coefficient that demonstrates the effect of monetary policy in this scenario. The same thing happened with inflation, exchange rates, and the covid-19 dummy. If the model shows that the interest rate effect is not considerable, as expected, according to the model. This contrasts with [10], who found that interest rate policies were only partially effective following the global financial crisis.

Moreover, the unit change in inflation brings about a 1 percent increase in the level of output at a significance level of 5\%, which shows a positive impact on economic growth but falls short of theoretical expectations. The impact of inflation on economic growth is large and detrimental. In principle, an increase in oil prices is one of the negative effects of inflation on Indonesian economic growth. If the price of fuel oil rises, the price of goods and services in the community will rise as well. The inflation rate in Indonesia will rise as the cost of goods and services rises.

According to the LPEM report [19], inflation during the Covid-19 pandemic in July was 1.52 percent year on year, up from 1.33 percent the previous month. Although core inflation dropped marginally, the strengthening of inflation was driven by the strengthening of government-regulated price components and volatile goods prices throughout this period. Inflation on the government-regulated price component was recorded at 0.61 percent, up from 0.49 percent the previous month. Core inflation, on the other hand, fell marginally from 1.49 percent in June 2021 to 1.40 percent in July 2021. However, the lowering of core inflation was insufficient to lower overall inflation year over year in this period.

A unit change in the exchange rate causes a decrease in economic growth of about 1,9 percent and is significant at $10 \%$, while a unit change in external reserves brings an increase in real GDP at a significant rate of $1 \%$. In theory, the effect of the exchange rate on economic growth depends on the preferences and monetary policy that accompanies the exchange rate regime, so that a fixed or floating exchange rate system can provide a higher rate of economic growth. According to an IDX Channel [20] release, the rupiah exchange rate is still swinging and tending to weaken in August 2021, while the stock market is agitated as the Composite Stock Price Index (JCI) is corrected rather thoroughly. The reduction in the rupiah exchange 
rate versus the US dollar is one of the negative consequences that the government should pay more attention to. Because, in this case, the rupiah exchange rate is connected to other economic indicators. Furthermore, the exchange rate variable's coefficient between monetary policy and other macroeconomic variables was found to be positive and significant, but the coefficient between exchange rate and interest rate was found to be negative and significant.

The money supply coefficient and the inflation rate are both significant, according to the results of the calculations. The significant link between money supply, inflation, exchange rate, and economic growth reflects these measures potential as necessary components for transferring monetary policy impulses to the aggregate economy. In Indonesia, meanwhile, the insignificant relationship between interest rates and the economy indicates that monetary policy is ineffective in influencing this macroeconomic variable during pandemic. The dominance of fiscal policy, especially government spending, in encouraging these macroeconomic variables, especially during the Covid-19 pandemic, supports this. Moreover, the insignificant relationship between the interest rate variable can be explained by the prudence of economic actors in transmitting monetary policy to the main variables in the economy, which are usually price stability and economic growth.

\section{Conclusions}

Based on the findings, the conclusions that can be drawn from this study are: The positive influence of Monetary Policy, in this case Money Supply, on economic growth has proven to be significant both in the period before and after the Covid-19 pandemic. The effect of deposit interest rates on economic growth has not been proven to have a negative and significant effect both in the period before and after the Covid-19 pandemic. The negative effect of inflation on economic growth has proven to be significant both in the period before and after the Covid-19 pandemic. The positive influence of the exchange rate on economic growth has proven to be significant both in the period before and after the Covid-19 pandemic. It is proven that Covid-19 causes activity levels to decrease compared to conditions before Covid19. The limitation of this research is Data. The data used is monthly data for the period 2015 (before the pandemic) to 2020 (during the Covid-19 pandemic). The policy implication of this study is that monetary policy during the pandemic has no effect on the economy, but the fiscal policy carried out by the government is appropriate to increase people's purchasing power.

\section{References}

[1] BPS. Ekonomi Indonesia 2019 Tumbuh 5,02 Persen. https://www.bps.go.id/pressrelease/2020/02/05/1755/ekonomi-indonesia-2019-tumbuh5-02-persen.html (2020).

[2] Kompas. Jokowi: GDP Kita Peringkat 16 Dunia Masih Mengeluh, Jangan Kufur Nikmat! https://nasional.kompas.com/read/2020/02/21/17471821/jokowi-gdp-kitaperingkat-16-dunia-masih-mengeluh-jangan-kufur-nikmat?source=clicktitle. (2020).

[3] Basri, F. Indonesia Ranking 7 Dunia. https:/faisalbasri.com/2020/02/23/indonesiaranking-7-dunia/faisal basri / Februari 23, 2020 (2020).

[4] Perekonomian Indonesia Pasca-Pandemi Covid-19. Kompas https://money.kompas.com/read/2020/05/10/091500226/perekonomian-indonesiapasca-pandemi-covid-19?page=all. (2020). 
[5] Precious, C. \& Palesa, M. K. Impact of Monetary Policy on Economic Growth: A Case Study of South Africa. Mediterr. J. Soc. Sci. 5, 76-84 (2014).

[6] Kamaan, C. K. The Effect of Monetary Policy on Economic Growth in Kenya. Int. J. Bus. Commer. 3, 11-24 (2014).

[7] Stiglitz, J. E. \& Weiss, A. Credit Rationing in Markets with Imperfect Information. Am. Econ. Rev. 71, 393-410 (1981).

[8] Bernanke, B. S. \& Blinder, A. S. The Federal Funds Rate and the Channels of Monetary Transmission. Am. Econ. Assoc. 82, 901-921 (1992).

[9] Christiano, L., Eichenbaum, M. \& Evans, C. Identification and the Effects of Monetary Policy Shocks. Federal Reserve Bank of Chicago Working Paper WP-94 7 (1994).

[10] Taylor, J. B. The Monetary Transmission Mechanism: An Empirical Framework. J. Econ. Perspect. 9, 11-26 (1995).

[11] Warjiyo, P. \& Solikin. Monetary Policy in Indonesia. Series Book No 6, Center for Central Banking Education and Studies, Bank Indonesia. (2003).

[12] Krishnankutty, R. Role of Banks Credit in Economic Growth: A Study with Special Reference to North East India. Econ. Res. Guard. 1, 60-71 (2011).

[13] Sergey, D., Alexandra, B., Pavel, T. \& Elena, S.-M. The Effect of Interest Rates on Economic Growth. Publ. Pap. 2017-303 (2017).

[14] Nazir, M. Metodologi Penelitian. Ghalia Indonesia, Jakarta (1988).

[15] Salim, J. F. Pengaruh Kebijakan Moneter terhadap Pertumbuhan Ekonomi di Indonesia. J. E-KOMBISI 3, 68-76 (2017).

[16] Bailliu, J., Lafrance, R. \& Perrault, J.-F. Does Exchange Rate Policy Matter for Growth? Bank Canada Work. Pap. No. 2002-17 (2002).

[17] Bacchetta, P. \& Wincoop, E. van. Does Exchange-Rate Stability Increase Trade and Welfare? Am. Econ. Rev. 90, 1093-1109 (2000)

[18] Gujarati, D. N. \& Porter, D. C. Dasar-Dasar Ekonometrika. Selemba Empat, Jakarta (2013).

[19] Nuryakin, C., Putratama, D. \& Rosdiyanti, Y. Seri Analisis Makroekonomi: Inflasi Bulanan. Agustus 2021. LPEM UI https:/www.lpem.org/id/seri-analisismakroekonomi-inflasi-bulanan.-agustus-2021/ (2021).

[20] Nurhaliza, S. Fluktuasi Ekonomi di Indonesia, Nilai Tukar Rupiah Terdampak Pandemi Covid-19. Market News https://www.idxchannel.com/market-news/fluktuasi-ekonomidi-indonesia-nilai-tukar-rupiah-terdampak-pandemi-covid-19 (2021).

[21] 21 bi.go.id, 2020 